\title{
STJ E NEXO CAUSAL NA RESPONSABILIDADE CIVIL AMBIENTAL
}

\author{
Paulo Affonso Leme Machado \\ Professor de Direito Ambiental - UNIMEP. Doutor em Direito- PUC-SP. Prêmio Elizabeth Haub \\ (Alemanha). Doutor Honoris Causa - Vermont Law School (USA), UNESP (Brasil) e Universidade \\ de Buenos Aires (Argentina). Professor Convidado na Universidade de Limoges (1986-2003). Mestre \\ pela Universidade Robert Schuman (Strasbourg/França). Chevalier de La Légion d'Honneur. Promo- \\ tor de Justiça (aposentado). \\ Email: paulo.leme.machado@uol.com.br
}

\section{RESUMO}

As consequências jurídicas do derramamento de óleo ocorrido no porto de Paranaguá - PR, Brasil, decorrente de uma explosão em um navio ocorrida em 2004, são analisadas neste artigo. Houve poluição de espaços vizinhos ao porto, ocasionando a interdição temporária da pesca. O navio carregava óleo e metanol. Não houve a entrega do metanol às empresas compradoras. O trabalho versa sobre o nexo causal na responsabilidade civil ambiental. Muitos pescadores recorreram das decisões judiciais, ocorrendo o que se chama de "recursos repetitivos". O julgamento pelo Superior Tribunal de Justiça ocorreu em2017. Como objetivos do artigo examinam-se duas teses de direito: não tendo havido tradição do metanol para as empresas compradoras, as mesmas não são responsáveis; a outra tese defende que todas as empresas são responsáveis, bastando o simples risco da atividade desenvolvida. Utilizou-se a metodologia comparativa da jurisprudência, legislação e doutrina.Como conclusão aponta-se ter o STJ julgado que a aplicação da responsabilidade objetiva ambiental implica na observância da teoria do risco integral, exigindo-se o nexo de causalidade entre a ação e o dano advindo.As empresas compradoras do metanol foram consideradas não responsáveis pelos danos ocorridos.

Palavras-chave: Poluição; nexo causal; responsabilidade objetiva ambiental. 


\author{
STJ AND CAUSAL NEXUS IN \\ ENVIRONMENTAL CIVIL LIABILITY
}

\begin{abstract}
:
The present article analyses the legal consequences of the oil spill that occurred in the port of Paranaguá - PR, Brazil, due to an explosion in a ship occurred in 2004. There was pollution of spaces neighboring the port, causing the temporary ban on fishing. The ship carried oil and methanol. There was no delivery of methanol to the purchasing companies. The article deals with the causal nexus in environmental civil liability. Many fishermen have appealed against the judicial decisions, taking place what is called "repetitive appeals". The judgment of the Superior Court of Justice (STJ) occurred in 2017. As objectives of this article, two main theses of law are examined: since there was no tradition of methanol for purchasers, they are not responsible; the other thesis argues that all companies are responsible, simply taking into account the risk of the activity developed. It was used the comparative methodology of jurisprudence, legislation and doctrine. As conclusion, it is highlighted that the STJ judged that the application of objective environmental liability implies the observance of the theory of integral risk, requiring the causal nexus between the action and the damage coming. The companies buying methanol were considered not responsible for the damages that occurred.
\end{abstract}

Keywords:Pollution; causal nexus; objective environmental liability. 


\title{
INTRODUÇÃO
}

Tratarei neste artigo do nexo de causalidade na responsabilidade civil ambiental conforme foi apreciada e julgada, no Recurso Especial $\mathrm{n}^{\mathrm{o}}$ 1.596.081 - PR (2016/0108822-1), em 25 de outubro de 2017, pelaSegunda Seção do Superior Tribunal de Justiça - STJ ${ }^{1}$.

\section{HISTÓRICO DO CASO E DO PROCESSO 1.1 Histórico do caso}

\author{
O Ministro Ricardo Villas Bôas Cueva (Relator), em seu voto, \\ destaca, no item n. 1,breve resumo do cenário fático-processual da \\ demanda:
}

"É fato notório e incontroverso que na noite de 15 de novembro de 2004, por volta das $19 \mathrm{~h} 45$, durante operação de descarga, no terminal privado da empresa CATTALINI TERMINAIS MARÍTIMOS, localizado em Paranaguá/PR, o navio tanque VICUÑA, de bandeira chilena, de propriedade da SOCIEDAD NAVIERA ULTRAGAZ, explodiu, causando - além da morte de 4 (quatro) de seus tripulantes, de avarias ao cais, às instalações do terminal e a pequenas embarcações próximas - a contaminação do ambiente pelo óleo combustível da embarcação (óleo bunker, óleo diesel e óleos lubrificantes) e por parte de sua carga (metanol).

O navio chegou ao Porto de Paranaguá transportando 11.226,521 toneladasdemetanol, produto que tinha as três empresas ora recorridas como destinatárias na seguinte proporção: 5.546,521 toneladas destinadas a BORDEN QUÍMICA INDÚSTRIA E COMÉRCIO LTDA. (atualmente denominada MOMENTIVE QUÍMICA DO BRASIL LTDA.), 3.670 toneladas destinadas a DYNEA BRASIL S.A. (atualmente incorporada por ARAUCO DO BRASIL S.A.) e 2.010 toneladas destinadas a SYNTEKO PRODUTOS QUÍMICOS S.A. (atualmente denominada GPC QUÍMICA S.A.).

No momento exato da explosão já haviam sido descarregadas, no terminalportuário, 7.147,288 toneladas do metanol transportado, restando, dessa forma, a bordo da embarcação 4.079,233 toneladas do produto que, em sua totalidade "queimouse, volatilizou-se ou ainda diluiu-se na água do mar nas primeiras horas, ou nos primeiros dias, após o acidente “(e-STJ fl. 118).”

$\overline{1}$ DJe: $22 / 11 / 2017$.

2 Documento: 1638872 - Inteiro Teor do Acórdão - Site certificado - DJe: 22/11/2017. 


\title{
1.2 Histórico do processo
}

"Trata-se de recurso especial interposto por LILIAN CARVALHO, com fulcro no art. 105, inciso III, alíneas “a” e “c”, da Constituição Federal, contra acórdão do Tribunal de Justiça do Estado do Paraná. Noticiam os autos que a ora recorrente ajuizou ação indenizatória em desfavor de BORDEN QUÍMICA INDÚSTRIA E COMÉRCIO LTDA. (atualmente denominada MOMENTIVE QUÍMICA DO BRASIL LTDA.), DYNEA BRASIL S.A. (atualmente incorporada por ARAUCO DO BRASIL S.A.) e SYNTEKO PRODUTOS QUÍMICOS S.A. (atualmente denominada GPC QUÍMICA S.A.), objetivando ser compensada por danos morais que teria suportado por ter sido temporariamente impedida de exercer sua profissão de pescadora em virtude do acidente ambiental relativo à explosão do navio VICUÑA, de bandeira chilena, em 15 de novembro de 2004, no Porto de Paranaguá.

Em sua petição inicial, sustentou a autora que as empresas requeridas seriam destinatárias (proprietárias) da carga transportada pelo navio VICUÑA no momento de sua explosão e que por isso seriam também solidariamente responsáveis pelos danos decorrentes do referido acidente, do qual resultou a contaminação ambiental (por óleo e metanol) e, consequentemente, a proibição da pesca, nas Baías de Paranaguá, Antonina e Guaraqueçaba, no litoral paranaense"3.

“O juízo de primeiro grau julgou improcedente o pedido autoral sob o fundamento de que (i) o dano moral, no caso em apreço, não teria sido comprovado e (ii) não haveria nexo causal entre a conduta das rés e o dano moral alegadamente suportado pela autora da demanda".

\subsection{Duas teses sobre o nexo de causalidade na responsabilidade objetiva ambiental}

\author{
Uma das teses, que ficou vencida no julgamento do STJ, foi a \\ abraçada pela $8^{\mathrm{a}}$ Câmara Cível do Estado do Paraná, é a seguinte:
}

“[...]a Oitava Câmara Cível do TJ/PR que, dando provimento ao recurso de apelação intentado pela autora, concluíram que a hipótese seria de responsabilidade objetiva com adoção da teoria do risco integral e que, ao contrário do que decidido pelo magistrado sentenciante, estaria, sim, configurado o nexo de causalidade, pois este consistiria na própria "atividade de risco indiretamente assumida pelas proprietárias da carga poluente transportada “ (e-STJ fl. 1.838).

3 Documento: 1638872 - Inteiro Teor do Acórdão - Site certificado - DJe: 22/11/2017. Relatório do Ministro Ricardo Villas Bôas Cueva (Relator). 
A outra tese, que ficou vencedora do STJ, foi a esposada pela $9^{\text {a }}$ Câmara Cível do Estado do Paraná:

“[...]a Nona Câmara Cível deste mesmo Tribunal, em idêntica situação, concluiu que a adição da teoria do risco integral não afasta a necessidade de comprovar a existência do nexo de causalidade, como pressuposto necessário para caracterizar a responsabilidade civil. E entende que, no caso, 'não há como estabelecer nexo de causalidade entre o simples fato de a carga transportada pelo navio ter sido adquirida pelas rés e os danos reclamados na inicial', concluindo que 'não se revela razoável imputar às rés a responsabilidade pelos prejuízos causados pela explosão do navio, já que o evento danoso ocorreu antes da tradição *

\section{DA APLICAÇÃO DA TEORIA DO RISCO INTEGRAL}

“[...] a responsabilidade por dano ambiental é objetiva, informada pela teoria do risco integral, sendo o nexo de causalidade o fator aglutinante que permite que o risco se integre na unidade do ato, sendo descabida a invocação, pela empresa responsável pelo dano ambiental, de excludentes de responsabilidade civil para afastar sua obrigação de indenizar “ (REsp n 1.374.284/MG, Rel. Ministro LUIS FELIPE SALOMÃO, SEGUNDA SEÇÃO, julgado em 27/8/2014, DJe de 5/9/2014 e REsp $n^{\circ} 1.354 .536 / \mathrm{SE}$, Rel. Ministro LUIS FELIPE SALOMÃO, SEGUNDA SEÇÃO, julgado em 26/3/2014, DJe de 5/5/2014).

PREQUESTIONAMENTO. INCIDÊNCIA DAS SÚMULAS N. 282 E 356 DO STF. ÔNUS PROBATÓRIO. INVERSÃO. PRECEDENTE. DESCONSTITUIÇÃO DA PROVA EMPRESTADA E NECESSIDADE DE PRODUÇÃO DE PROVA SUPLEMENTAR. ANÁLISE. ÓBICE DA SÚMULA N. 7/STJ. DECISÃO MANTIDA. 1. A simples indicação dos dispositivos legais tidos por violados, sem que o tema tenha sido enfrentado pelo acórdão recorrido, obsta o conhecimento do recurso especial, por falta de prequestionamento, a teor das Súmulas n. 282 e 356 do STF. 2. Tratando-se de ação indenizatória por dano ambiental, a responsabilidade pelos danos causados é objetiva, pois fundada na teoria do risco integral. Assim, cabível a inversão do ônus da prova. Precedente. 3. O recurso especial não comporta o exame de questões que impliquem revolvimento do contexto fático-probatório dos autos, a teor do que dispõe a Súmula n. 7 do STJ. 4. Agravo regimental a que se nega provimento. “ (AgRg no AREsp nº 533.786/RJ, Rel. Ministro ANTONIO CARLOS FERREIRA, QUARTA TURMA, julgado em 22/9/2015, DJe de 29/9/2015 - grifou$\mathrm{se})$.

"RECURSO ESPECIAL. RESPONSABILIDADE CIVIL. DANO AMBIENTAL 
PRIVADO. RESÍDUO INDUSTRIAL. QUEIMADURAS EM ADOLESCENTE. REPARAÇÃO DOS DANOS MATERIAIS E MORAIS. 1 - Demanda indenizatória movida por jovem que sofreu graves queimaduras nas pernas ao manter contato com resíduo industrial depositado em área rural. 2 - A responsabilidade civil por danos ambientais, seja por lesão ao meio ambiente propriamente dito (dano ambiental público), seja por ofensa a direitos individuais (dano ambiental privado), é objetiva, fundada na teoria do risco integral, em face do disposto no art. $14, \S 10^{\circ}$, da Lei n. 6.938/81. 3 - A colocação de placas no local indicando a presença de material orgânico não é suficiente para excluir a responsabilidade civil. 4 - Irrelevância da eventual culpa exclusiva ou concorrente da vítima. 5 - Quantum indenizatório arbitrado com razoabilidade pelas instâncias de origem. Súmula 07/ STJ. 6 - Alteração do termo inicial da correção monetária (Súmula 362/STJ). 7 RECURSO ESPECIAL PARCIALMENTE PROVIDO. “ (REsp n 1.373.788/SP, Rel. Ministro PAULO DE TARSO SANSEVERINO, TERCEIRA TURMA, julgado em 6/5/2014, DJe de 20/5/2014 - grifou-se).

A jurisprudência do STJ, mencionada nos três julgados, mostra, com clareza, que a aplicação da teoria do risco integral na responsabilidade objetiva ambiental exige a comprovação do nexo causal entre a autoria e o dano ambiental.

\section{A NÃO TRADIÇÃO DO PRODUTO VENDIDO}

As empresas compradoras do metanol afirmam a sua não participação em nenhum fato gerador de responsabilidade civil com relação às explosões e incêndio no navio Vicuña e consequente poluição do mar e de espécies marinhas e a suspensão da pesca pela razão de não serem proprietárias do produto metanol, existente na referida embarcação.

As mencionadas empresas apontam que o produto comprado não chegou a lhes ser entregue. Com apoio no art. 492 do Código Civil Brasileiro afirmam que a responsabilidade é do vendedor.

Art. 492 do Código Civil Brasileiro:

"Até o momento da tradição, os riscos da coisa correm por conta do vendedor, e os do preço por conta do comprador".

\footnotetext{
"As consequências básicas do contrato de compra e venda consistem, de um lado, na obrigação do vendedor transferir a propriedade da res e, de outro, na responsabilidade
} 
de o comprador efetuar o pagamento. Cumpre a quem vende efetuar a tradição, a fim de que o comprador adquira o domínio sobre a coisa móvel". (NADER, 2013, p. 165)

O produto comprado pelas empresas mencionadas, que não lhes foi entregue, impossibilitou-as de exercer o direito de propriedade - usar, gozar e dispor da coisa (art. 1.228 CCB).Sabiamente a Lei civil procura impulsionar o vendedor a ter cuidado com a coisa objeto da venda e, dessa forma, faz com que os riscos da coisa corram por sua conta, até o momento da tradição.

“Assim, no intervalo que separa a contratação da tradição - disponibilização da coisa ao comprador - o negócio jurídico opera efeitos de ordem meramente obrigacionais e os riscos da coisa serão imputados ao alienante.” (ROSEVALD, 2011, p. 549).

O Ministro Luís Felipe Salomão fez constar em seu voto:

[...]"o código CFR implica que o vendedor se responsabilize por embalar, identificar a mercadoria, desembaraçar a mercadoria na alfândega do seu país, contratar e pagar o frete e desembarcar a mercadoria no porto de destino. O código incoterm é harmônico com o disposto no art. 234 do Código Civil, pois permite que os contratantes, em obrigação de dar, estabeleçam regras diversas quanto à distribuição dos riscos - que se limitam à perda da coisa (FARIAS, Cristiano Chaves de; ROSENVALD, Nelson Curso de direito civil: obrigações. 11 ed. Salvador: Juspodivm, 2017, p. 180-183). Aliás, o Código Civil de 2002 promoveu a unificação contratual, regulando contratos internos e internacionais. Mutatis mutandis, o art. 502 do CC esclarece que o vendedor, salvo convenção em contrário, responde por todos os débitos que gravem a coisa até o momento da tradição. Por um lado, dispõe o art. 237 do CC que até a tradição pertence ao devedor a coisa. E o art. 1.226 estabelece que os direitos reais sobre coisas móveis, quando constituídos, ou transmitidos por atos entre vivos, só se adquirem com a tradição". ${ }^{4}$

\section{LEGISLAÇÃO SOBRE SEGURANÇA DO TRANSPORTE MARÍTIMO}

Dispõe a Lei n. 7.003, de 03/07/1984:

Art. $3^{\circ}$ - Quando a embarcação, coisa ou bem em perigo representar um risco de dano a terceiros ou ao meio ambiente, o armador ou o proprietário, conforme o caso, será o responsável pelas providências necessárias para anular ou minimizar esse risco e,

4 Documento: 1638873 - Inteiro Teor do Acórdão - Site certificado - DJe: 22/11/2017 Página 32. 
caso o dano se concretize, pelas suas consequências sobre terceiros ou sobre o meio ambiente, sem prejuízo do direito regressivo que lhe possa corresponder.

O armador ou o proprietário do navio, quando a embarcação, as coisas ou os bens representarem um risco de danos a terceiros ou ao meio ambiente, será o responsável pelas providências necessárias para anular o risco. Se o dano vier a ocorrer, o armador ou o proprietário serão responsáveis sobre terceiros ou sobre o meio ambiente, sem prejuízo do direito regressivo que lhe possa corresponder.

Vale lembrar o sistema jurídico sobre responsabilidade adotado pela Convenção Internacional sobre responsabilidade civil em danos causados por poluição por óleo ( Decreto Legislativo n. 74, de 30/09/74). A carga transportada pelo navio Vicuñacontinha óleo e, também, metanol. Oportuno apontar o teor do art. $3^{\circ}$ da citada Convenção Internacional:

[...] "o proprietário do navio no momento do incidente, ou se o incidente consiste de sucessão de fatos, no momento do primeiro fato, será responsável por qualquer dano por poluição causado por óleo que tenha sido derramadodescarregado de seu navio como resultado do incidente".

A Convenção Internacional comentada estabeleceu, de forma clara e incisiva, que o proprietário do navio responde pelos danos causados pela poluição- no caso - proveniente do óleo. O proprietário fica isento de responsabilidade se provar que os danos decorreram de guerra, que foram resultados da ação de terceiros ou da própria vítima.

Dessa forma, nãoé cabível pretender-se imputar a responsabilidade direta ou indireta das empresas compradoras de metanol sobre as providências que foram ou não tomadas no interior da embarcação, pois essas medidas cabiam integralmente ao armador ou ao proprietário do navio Vicuña.

\section{A LEI DE POLÍTICA NACIONAL DO MEIO AMBIENTE/1981 E A RESPONSABILIDADE CIVIL OBJETIVA}

\footnotetext{
“A Lei n. 6.938/81 é, pelo menos de acordo com a avaliação geral, o“divisor de águas”, tendo determinado o início da etapa que aqui denominamos de fase sistemáticovalorativa, sendo que apenas após a sua edição e do consequente reconhecimento da autonomia normativa dos valores ecológicos e do bem jurídico ambiental, é
} 
que se pode falar de um Direito Ambiental brasileiro com real expressão e suporte normativo".(SARLET, MACHADO. eFENSTERSEIFER, 2015, p. 24).

\subsection{A responsabilidade civil objetiva ambiental: autoria e dano}

"A obrigação de indenizar sem culpa nasce por ministério da lei, para certos casos, por duas razões: $1^{\text {a }}$ ) consideração de que certas atividades do homem criam um risco especial para os outros; $2^{\mathrm{a}}$ ) a consideração de que o exercício de determinados direitos deve implicar a obrigação de ressarcir os danos que origina". (GOMES, 2011, p. 113)

Trago o texto da Lei n. 6.938/1981 - art. 14, que trata da matéria:

“§ $1^{\circ}$ - Sem obstar a aplicação das penalidades previstas neste artigo, é o poluidor obrigado, independentemente da existência de culpa, a indenizar ou reparar os danos causados ao meio ambiente e a terceiros, afetados por sua atividade. O Ministério Público da União e dos Estados terá legitimidade para propor ação de responsabilidade civil e criminal, por danos causados ao meio ambiente.

"A responsabilidade objetiva ambiental significa que quem danificar o ambiente tem o dever jurídico de repará-lo. Presente, pois, o binômio dano/reparação. Não se pergunta a razão da degradação para que haja o dever de indenizar e/ou reparar. A responsabilidade sem culpa tem incidência na indenização ou na reparação dos "danos causados ao meio ambiente e aos terceiros afetados por sua atividade" (art.

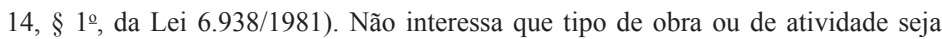
exercida pelo que degrada, pois não há necessidade de que ela apresente risco ou seja perigosa. Procura-se quem foi atingido e, se for o meio ambiente e o homem, iniciase o processo lógico-jurídico da imputação civil objetiva ambiental. Só depois é que se entrará na fase do estabelecimento do nexo de causalidade entre a ação ou omissão e o dano". (MACHADO, 2017, p. 416).

A redação do $\S 1^{\circ}$ do art. 14 da Lei 6.938 normatiza o critério da reparação dos danos causados ao meio ambiente e a terceiros. Não se pode negar que a reparação dos prejuízos ambientais é importante, mas também é relevante prevenir os danos. A responsabilidade sem culpa visa "forçar o potencial poluidor do meio ambiente a adaptar o próprio nível de atividade em função da probabilidade de causar um dano ambiental". (POZZO,1996, 
p. 278-279)

Merece ser apontada a diferença na gênese dos modelos de responsabilidade sem culpa - o constante da Lei de Política Nacional do Meio Ambiente, de 1981, e o do Código Civil Brasileiro, de 2002. São 21 anos que distanciam uma lei da outra. Na Lei n. 6.938/1981 pensouse "vir ao encontro também das necessidades da vítima, que, em caso de responsabilidade baseada na culpa, estaria enfrentando a difícil tarefa de ter que provar negligência do agente". (POZZO,1996, p. 278-279) Com o maior respeito, essa minha interpretação é a de quem teve o encargo histórico de redigir o mencionado $\S 1^{\circ}$ do art. 14 da Lei 6.938, como memorizou o então Secretário Especial do Meio Ambiente, Prof. Dr. Paulo Nogueira Neto. (NOGUEIRA NETO, 2010, p. 225).

Na Lei de 1981 não se levou em conta o que hoje consta do Código Civil, de 2002: “... ou quando a atividade normalmente desenvolvida pelo autor do dano implicar, por sua natureza, risco para os direitos de outrem" (art. 927, Parágrafo único). Por isso, é que me manifestei acima, dizendo que na responsabilidade objetiva ambiental "não se pergunta a razão da degradação para que haja o dever de indenizar e/ou reparar". "A responsabilidade civil assenta-se na conduta do agente (responsabilidade subjetiva) ou no fato da coisa ou no risco da atividade (responsabilidade objetiva).”(NERY JR. ENERY, 2008, p. 735). O controle do risco ambiental só encontrou maior acolhida em 1988, no art. 225 da Constituição e na Declaração Rio de Janeiro/1992, com o princípio da precaução e, depois, no próprio Código Civil.

\subsection{A responsabilidade civil ambiental e o nexo de causalidade}

"A exigência de uma relação de necessidade entre o fato gerador e o dano conduzirá naturalmente os tribunais a afastar o nexo de causalidade, a cada vez que o acontecimento em questão não apareça como uma condição sine qua non do dano" (VINEY e JOURDAIN, 2013, p.255).

$\mathrm{O}$ evento retratado no processo vertente mostra que o incêndio e as explosões acontecidas no navio Vicuña somente apontam a autoria do dano para a proprietária do navio Sociedad Naviera Ultragas Ltda e para a empresa Catalini Terminais Marítimos, onde o navio estava atracado, em operação de descarga. As empresas compradoras da carga e que não chegaram a receber o produto embarcado, somente pelo fato de serem compradoras desse produto, não podem ser imputadas como 
corresponsáveis pelos danos ambientais ocorridos.

Destaco a doutrina que entende odano como efeito necessário de uma determinada causa.: "a teoria da causalidade adequada somente considerará como causadora do dano a condição por si só apta a produzilo". (GONÇALVES, 2017, p. 362)

No caso em exame, a condição necessária para a ocorrência das explosões e do incêndio no navio Vicuña decorreu da ação e da omissãoda proprietária do navio Sociedad Naviera Ultragas Ltda e da empresa Catalini Terminais Marítimos, onde o navio estava atracado, em operação de descarga.

\subsection{Não ocorrência do nexo de causalidade no caso do navio Vicuña com referência às empresas compradoras do metanol}

'4. Em que pese a responsabilidade por dano ambiental seja objetiva (e lastreada pela teoria do risco integral), faz-se imprescindível, para a configuração do dever de indenizar, a demonstração da existência de nexo de causalidade apto a vincular o resultado lesivo efetivamente verificado ao comportamento (comissivo ou omissivo) daquele a quem se repute a condição de agente causador. 5. No caso, inexiste nexo de causalidade entre os danos ambientais (e morais a eles correlatos) resultantes da explosão do navio Vicuña e a conduta das empresas adquirentes da carga transportada pela referida embarcação"s

As empresas adquirentes do metanol não tinham nenhuma autoridade sobre o navio que transportava o metanol.

Asmencionadas empresas não eram responsáveis pela manutenção da embarcação, não possuindo, assim, capacidade de impedir o evento danoso (já que o laudo técnico acostado aos autos apontou a ausência de manutenção do navio como causa de sua explosão).

'Não se revela razoável afirmar também que a responsabilização das recorrentes seria resultado lógico de eventual comportamento omissivo de sua parte, pois este, como consabido, só se verifica nas hipóteses em que o agente (suposto poluidor), tendo o dever de impedir a degradação, deixa mesmo assim de fazê-lo, beneficiando-se, ainda que de forma indireta, do comportamento de terceiro diretamente responsável pelo dano causado ao meio ambiente". ${ }^{6}$

5 Documento: 1638873 - Inteiro Teor do Acórdão - Site certificado - DJe: 22/11/2017, p. 1

6 Documento: 1638873 - Inteiro Teor do Acórdão - Site certificado - DJe: 22/11/2017, p. 18. Superior Tribunal de Justiça. Voto do Ministro Ricardo Villas Bôas Cueva. 
Não se pode afirmar que os riscos próprios ao transporte marítimo estivessem relacionados com as atividades das empresas compradoras do metanol. Disse o Ministro Relator Ricardo Villas Bôas Cueva:

\footnotetext{
"Tais riscos - justificadores da aplicação ao caso da teoria do risco integral - eram próprios das atividades econômicas da SOCIEDAD NAVIERA ULTRAGAZ (a proprietária da embarcação envolvida no incidente objeto da lide) e da empresa CATTALINI TERMINAIS MARÍTIMOS (responsável pela exploração do terminal portuário onde se deu o evento danoso). Quando muito, seria razoável estender a responsabilidade proveniente da assunção desse risco à empresa vendedora da carga (METHANEX CHILE LIMITED), haja vista ter sido ela, na espécie, a contratante do serviço de transporte" ".

O Ministro Luís Felipe Salomão, em seu voto vista, manifestou-se dizendo:

"Evidentemente, adquirir regularmente mercadoria para servir de insumo para produção industrial não é sancionado ou mesmo desestimulado pela lei, não havendo como conceber, a meu juízo, nenhum desvalor jurídico no tocante à conduta das recorrentes, tampouco dano indenizável decorrente desse ato isolado de vincular-se obrigacionalmente para aquisição de matéria-prima". ${ }^{8}$
}

O fato de comprar-se uma mercadoria para servir de insumo industrial não é sancionado ou mesmo desestimulado pela lei. E, no caso presente, não influiu na ocorrência da explosão e do incêndio ocorrido no navio Vicuña.

\subsection{Inaplicabilidade da teoria da responsabilidade vinculada ao risco do processo produtivo}

Essa teoria não foi aceita no caso do navio Vicuña, sendo a Segunda Seção, que acolheu os entendimentos expostos pelo Ministro Ricardo Villas Bôas Cueva e Luís Felipe Salomão. Este último acentuou em seu voto:

\footnotetext{
"A ideia fundamental da doutrina é a de que só há uma relação de causalidade adequada entre fato e dano quando o ato praticado pelo agente seja de molde a provocar o dano sofrido pela vítima, segundo o curso normal das coisas e a experiência comum da vida". 9
}

\footnotetext{
7 Documento: 1638873 - Inteiro Teor do Acórdão - Site certificado - DJe: 22/11/2017 Página 18-19 Superior Tribunal de Justiça

8 Documento: 1638873 - Inteiro Teor do Acórdão - Site certificado - DJe: 22/11/2017 Página 39.

9 Documento: 1638873 - Inteiro Teor do Acórdão - Site certificado - DJe: 22/11/2017 Página 39.
} 
A sabedoria dos juízes não contraria a sabedoria popular, por isso é muito adequado que o magistrado da terceira instância invoque a "experiência comum da vida". O simples fato de comprar-se um produto não torna o comprador responsável pela poluição inicial, acaso existente na linha de produção do produto. Isso seria uma aplicação extremada do princípio poluidor-pagador, que contraria "o curso normal das coisas". "A ideia de normalidade está em ligação com a ideia de probabilidade: parece normal aquilo que se produz frequentemente, portanto aquilo que tem uma probabilidade de ocorrência elevada". (POUILLAUDE, 2011, p.76)

Alguns poderiam acenar para a chamada "responsabilidade compartilhada", existente na Lei de Política Nacional de Resíduos Sólidos. Desde o início, salienta-se que a responsabilidade compartilhada não se alastra indefinidamente, mas tem seus limites na própria Lei e nos acordos setoriais, voluntariamente celebrados.

\footnotetext{
"Ressalte-se que o primeiro objetivo da responsabilidade compartilhada é compatibilizar os interesses entre os agentes econômicos e sociais, na gestão empresarial e mercadológica, com os interesses da gestão ambiental, utilizando-se de estratégias sustentáveis (conforme o art. 30, Parágrafo único, I da Lei 12.305/2010)”. (MACHADO, 2017, p. 686).

“A responsabilidade civil objetiva ambiental é o grande guarda-chuva que abarca todos os campos do direito ambiental: águas, atmosfera, solos, fauna, florestas e, também, resíduos sólidos. Embaixo desse amplo guarda-chuva da responsabilidade civil objetiva ambiental situa-se a responsabilidade compartilhada. A responsabilidade compartilhada não substitui a responsabilidade civil objetiva, nem a enfraquece e nem a aumenta. Ela personaliza o relacionamento dessas duas responsabilidades, numa relação jurídica "individualizada e encadeada", de contextura econômica, ambiental e social especial: a da geração e da gestão de resíduos, previamente nominadas pela Lei ou pelos acordos setoriais e pelos termos de compromisso".(MACHADO, 2017, p. 687)
}

A responsabilidade civil independentemente de culpa, "quando a atividade normalmente desenvolvida pelo autor do dano implicar, por sua natureza,, risco para os direitos de outrem” (art. 927, Parágrafo único, do Código Civil ) pressupõe, pelo menos, dois elementos. Primeiro, que haja a nítida caracterização do autor do dano, pois, do contrário, seria uma imputação arbitrária e não veraz. O segundo elemento é a identificação concreta do risco, que não pode cair no terreno da conjectura ou da 
mera suposição. "A decisão administrativa que invocar o princípio da precaução deverá evitar a queda na arbitrariedade; e, para isso, terá que apresentar os elementos de incerteza ou de dúvida, apoiando-se o ato administrativo, entre outros fundamentos, na legalidade, na razoabilidade e na proporcionalidade". (MACHADO, 2017, p. 113).

Em sentido favorável à tese da responsabilidade objetiva vinculada ao risco do processo produtivo, indica-se o seguinte ponto de vista: "Todos os riscos abrangidos pela atividade deverão ser internalizados no processo produtivo e, se o dano ocorrer, haverá uma presunção de causalidade entre tais riscos e o dano. "(STEIGLEDER, 2004, p. 204).

\subsection{Poluidor indireto, responsabilidade civil objetiva ambiental e o caso do processo}

Na Lei de Política Nacional do Meio Ambiente consta no art. $3^{\circ}$ que poluição é a degradação ambiental resultante de atividades cometidas de forma direta ou indireta (inciso III) e que conceitua poluidor como "a pessoa física ou jurídica, responsável, direta ou indiretamente, por atividade causadora de degradação ambiental" (inciso IV).

Poluidor direto é o que pratica a poluição de forma decisiva e principal. Poluidor indireto é aquele ajuda na prática da poluição. Tanto o agente direto como o agente indireto para serem responsáveis civilmente como "poluidor" precisam agir de forma a causarpoluição direta ou poluição indireta. .

Para ser poluidor indireto (art. $3^{\circ}$, IV e III la Lei 6.938/1981) - pessoa física ou pessoa jurídica - é preciso que se prove que ele tenha causado, através de sua ação ou omissão, degradação da qualidade ambiental, de que resulte:
a)prejuízo à saúde, à segurança e ao bem-estar da população;
b)condições adversas às atividades sociais e econômicas;
c)ofensa desfavorável à biota:
d)ofensa às condições estéticas ou sanitárias do meio ambiente;
e) lançamento de matérias ou energia em desacordo com padrõesambientais estabelecidos.

Trago à colação julgado do STJ que se refere a várias formas de cometimento da poluição direta e indireta. 
"Para o fim de apuração do nexo de causalidade no dano ambiental, equiparamse quem faz, quem não faz, quando deveria fazer, quem deixa fazer, quem não se importa que façam, quem financia para que façam, quem cala quando tinha o dever de denunciar, e quem se beneficia quando outros fazem”. Recurso Especial n. 1.186.130 -RJ, Relator Ministro Herman Benjamin:

São sete hipóteses e, sobre cada uma, procurarei analisar a conduta das empresas compradoras do metanol.

\subsubsection{Quem faz}

As empresas compradoras do metanol não fizeram nada que as envolvesse na ação ocorrida no navio Vicuña, no dia e hora em que ocorreram as explosões e incêndio no referido navio. Pelo fato de terem adquirido produtos, que não lhes foram entregues, não praticaram poluição direta ou indireta.

\subsubsection{Quem não faz, quando deveria fazer}

As empresas compradoras do metanol não tiveram nenhuma possibilidade de prevenir os danos ambientais ocorridos. Não intervieram no combate ao incêndio ocorrido, pois para isso estava presente o Corpo de Bombeiros. Não tinham qualquer poder para interferir nos procedimentos de desembargue tanto no navio, como no terminal marítimo.

"o poluidor-que-deve-pagar é quem efectivamente cria e controla as condições em que a poluição se produz, que neste caso é o produtor. A sua actuação foi condição sine qua non da poluição, e só ele dispõe de meios para a evitar. É certo que o consumidor também é um poluidor indirecto, que beneficia de um produto cuja produção foi prejudicial para a sociedade, mas ele não tem ao seu alcance meios razoáveis para evitar a ocorrência do dano, porque não controla as condições em que a poluição acontece. Exigir uma cessação total da actividade indirectamente poluente (o consumo) como forma de controlar a poluição é manifestamente irrazoável, quando existam outros meios menos onerosos de evitar a poluição.” (ARAGÃO, 1997, p. $140-141)$.

\subsubsection{Quem deixa fazer}

As empresas compradoras do metanol não tiveram nenhuma 
atitude omissiva, deixando que se fizesse algo contra a legislação ambiental. O produto comprado era regularmente admitido para o transporte marítimo. Nada estava sendo feito às escondidas ou ao arrepio da legislação de segurança e de meio ambiente.

\subsubsection{Quem não se importa que façam}

As empresas compradoras do metanol dão importância à legalidade de suas condutas. Não desprezam o meio ambiente e valorizam o trabalho dos pescadores. Foi um acidente lamentável, e em nada contribuíram para a sua ocorrência. Cabe, sim, aos Legisladores preverem normas mais estritas de segurança do transporte marítimo. Ao efetuarem a compra do produto transportado as empresas estavam atuando legitimamente e dando emprego a pessoas e famílias que possibilitam o desenvolvimento sustentável do Brasil.

\subsubsection{Quem financia para que façam}

As empresas compradoras do metanol não financiaram a poluição direta ou indireta. Elas também sofreram economicamente, porque não lhes foi entregue a mercadoria de que precisavam para exercer a atividade econômica que desempenham.

\subsubsection{Quem cala quando tinha o dever de denunciar}

As empresas compradoras do metanol não se calaram, como não agiram clandestinamente. Elas não tiveram que denunciar a empresa proprietária do navio e nem a empresa responsável pelo terminal marítimo, porque prontamente a Capitania dos Portos, o Instituto Ambiental do Paraná e o IBAMA tomaram as providências que lhes são devidas, tendo o caso sido apreciado, também, pelo Tribunal Marítimo.

5.5.7Quem se beneficia quando outros fazem:

As empresas compradoras do metanol não tiveram nenhum benefício com a ocorrência das explosões e incêndio no navio Vicuña e, também, não tiveram nenhum benefício com a suspensão da pesca. Contraria a lógica normal dos fatos, ou o que comumente acontece na vida cotidiana, que as empresas retirem qualquer benefício com a ação ou a omissão da proprietária do navio e do terminal marítimo. Estas empresas são as exclusivas responsáveis pela poluição e pelo ressarcimento dos danos.

Mostrou-se amplamente que não se tem fundamento para invocar a solidariedade no sentido de imputar responsabilidade às empresas compradoras do metanol. 
"A obrigação in solidum deve, como pensamos, permanecer uma solução subsidiária que cede lugar à responsabilidade individual, desde que uma luz possa ser feita sobre a causalidade. Em consequência, se um dos acusados consegue estabelecer, dentre eles, quem está na origem do dano, todos os outros devem ser liberados de pleno direito. E se ele pode provar sua não participação, deve ser liberado de qualquer responsabilidade". (VINEY e JOURDAIN, 2013, p. 307).

\title{
6. A TESE ACOLHIDA PELO STF HARMONIZA-SE COM O DESENVOLVIMENTO SUSTENTÁVEL
}

\subsection{O desenvolvimento sustentável na Declaração de Estocolmo/1972.}

\section{A Declaração de Estocolmo sobre Meio Ambiente/1972, contém} sete pontos no seu preâmbulo. $O$ primeiro ponto diz:

\begin{abstract}
"O homem é, às vezes, criatura e criador de seu meio ambiente, que assegura sua subsistência física e oferece-lhe a possibilidade de desenvolvimento intelectual, moral, social e espiritual. Na longa e laboriosa evolução da raça humana sobre a Terra, o momento é chegado, onde graças aos progressos sempre mais rápidos da ciência e da tecnologia, o homem adquiriu o poder de transformar seu meio ambiente, de inúmeras maneiras e numa escala sem precedente. Os dois elementos de seu meio ambiente, o elemento natural e aquele que ele mesmo cria, são indispensáveis ao seu bem- estar e à plena fruição de seus direitos fundamentais, neles compreendidos o direito à própria vida."10
\end{abstract}

Interessa salientar que na Declaração de Estocolmo/1972 foi inserido, no n. 1 que o ser humano"tem o dever solene de proteger e de melhorar o meio ambiente para as gerações presentes e futuras". Nessa afirmação está a semente internacional do princípio da sustentabilidade, que irá tendo uma configuração mais definida e ampliada nos próximos documentos internacionais.

10 Conferência das Nações Unidas sobre o Meio Ambiente, reunida em Estocolmo de 5 a 16 de junho de 1972. Recueil Francophone des Traitès Internationaux en Droit de L'Environnement. Bruxelles : Brylant. p. 27, 1998. (minha tradução). 


\subsection{O desenvolvimento sustentável na Declaração de Janeiro/1992.}

"Nos vinte e sete princípios da Declaração Rio de Janeiro/92 encontramos, em pelo menos onze, a utilização do conceito de desenvolvimento sustentado”. (MACHADO, 1993, p. 217). “A ideia de durabilidade do desenvolvimento corresponde ao sentido de um desenvolvimento permanente, transmitido, não interrompido numa geração. É adequado falar-se em patrimônio ambiental. O patrimônio ambiental não é uma noção só de presente, pois ele supõe o direito de recebê-lo do passado e de entregá-lo para o futuro". (MACHADO, 1993, p. 218).

"A dimensão ambiental da sustentabilidade" trata da "dimensão ambiental, no sentido de que existe dignidade do ambiente, assim como se reconhece o direito das gerações atuais, sem prejuízo das futuras, ao ambiente limpo, em todos os aspectos. Desse modo, como a degradação ambiental pode inviabilizar a vida humana (e já inviabilizou civilizações), incontornável o seu enfrentamento hábil e tempestivo". (FREITAS, Juarez, 2011, p. 60-61).

\subsection{O desenvolvimento sustentável na Decisão da Corte Permanente de Arbitragem de Haya.}

A Corte Permanente de Arbitragem de Haya é um tribunal "sui generis", pois é composto de três juízes da Corte Internacional de Justiça - organismo que integra a Organização das Nações Unidas - e de dois juristas, que não compõem a CIJ. Trago para análise o caso _ "Reno de Ferro" (IJzeren Rijn), que retrata um desacordo entre a Bélgica e os Países Baixos sobre uma atividade econômica, que teve incidência direta sobre o meio ambiente. Em síntese: construiu-se uma ferrovia, por volta de 1879, que partia da Bélgica, atravessava parte dos Países Baixos e terminava na Alemanha, visando, principalmente, a circulação de mercadorias. Após a primeira guerra mundial a utilização da ferrovia foi diminuindo. Os Países Baixos tomaram medidas para a implantação de reservas naturais nos espaços ocupados pela ferrovia, mas a Bélgica quis voltar a utilizar esse espaço, sendo o différend apresentado à mencionada Corte de Arbitragem. A Corte emitiu sua decisão em 20 de setembro de 2005.

Válido citar-se uma parte da decisão em que se trata dos princípios a serem observadosnos embates entre meio ambiente e desenvolvimento.

"Depois da Conferência de Estocolmo sobre Meio Ambiente de 1972, o direito internacional relativo à proteção ambiental conheceu um avanço notório. 
Atualmente, o direito internacional e o direito comunitário exigem a integração das medidas apropriadas de proteção do meio ambiente na concepção e na execução das atividades de desenvolvimento econômico. O princípio 4 da Declaração do Rio de Janeiro sobre meio ambiente e desenvolvimento, adotada em 1992, que reflete esta tendência, prevê que a "proteção do meio ambiente deve fazer parte integrante do processo de desenvolvimento e não pode ser considerada isoladamente". O ponto importante é que estes princípios emergentes integram, desde já, a proteção no processo de desenvolvimento.O direito ambiental e o direito ao desenvolvimento existem não como alternativas, mas como mútuo reforço, conceitos que se integram, exigindo que, quando o desenvolvimento possa causar significativo prejuízo para o meio ambiente, haja o dever de prevenir ou, pelo menos, de reduzir esse prejuízo.Este dever, na opinião do Tribunal tornou-se agora um princípio de direito internacional geral. Este princípio aplica-se não só em atividades autônomas, mas, também, em atividades realizadas na implementação de tratados específicos entre as partes. O Tribunal reitera a observação da Corte Internacional de Justiça, no caso GabcikovoMagymaros, segundo a qual "o conceito de desenvolvimento sustentado traduz bem esta necessidade de conciliar o desenvolvimento econômico e a proteção do meio ambiente" (Gabcikovo-Nagymaros (Hungria/Eslováquia), Julgado. Recueil CIJ, 1997, p. 7-p.78, § 140). ${ }^{11}$

\section{CONCLUSÃO}

A decisão unânime da Segunda Seção do Superior Tribunal de Justiça isentou de responsabilidade civilas empresas que compraram metanol, mas que não chegaram a receber esse produto. Não foi reconhecida na operação de compra do produto uma ação poluidora indireta. O Tribunal, assim entendendo, não quis enfraquecer a proteção do meio ambiente, pois existiram outros agentes relacionados diretamente com a explosão e incêndio do navio Vicuña. Não ocorreu uma decisão judicial específica quanto aos outros agentes - a empresa vendedora do produto, a empresa proprietária do navio e o terminal marítimo - pela razão de eles não integrarem os processos como réus. Não houve um predomínio abusivo da economia na decisão do STJ, mas se observou o itinerário do desenvolvimento econômico sustentável, que prevê segurança jurídica e integração do direito ao meio ambiente com o direito ao desenvolvimento.

Estou convencido da justeza da decisão da Corte Permanente de Arbitragem de Haya,já mencionada, que afirma:"quando o desenvolvimento

11 https://pcacases.com/web/sendAttach/481, § 59. Acesso em 23/12/2017. (Minha tradução) 
possa causar significativo prejuízo para o meio ambiente, haja o dever de prevenir ou, pelo menos, de reduzir esse prejuízo", com a qual se harmoniza a decisão da Segunda Turma do Superior Tribunal de Justiça, no caso do navio Vicuña.. A proteção ambiental deve ser feita dentro das regras do Estado de Direito. Não será alargando, de forma desarrazoada a responsabilidade objetiva, sem provar concretamente o risco da atividade econômica, que será construída uma sociedade ecologicamente justa. A prevenção dos acidentes marítimos causadores de poluição ambiental - nos navios como nos terminais marítimos - tem sido intensamente reclamada, mas pouco efetivada. A prevenção, sem dúvida, é o pilar jurídico indispensável do direito constitucional de todos ao meio ambiente ecologicamente equilibrado.

\section{REFERÊNCIAS}

ARAGÃO, Maria Alexandrade Sousa.O Princípio do Poluidor Pagador - pedra angular da política comunitária do ambiente. Coimbra: Coimbra Editora, 1997.

FREITAS, Juarez. Sustentabilidade: direito ao futuro. Belo Horizonte: Fórum, 2011.

GOMES , Orlando. Responsabilidade Civil. Atualizador: Edvaldo Brito. Rio de Janeiro: Forense,2011.

GONÇALVES, Carlos Roberto.Direito Civil Brasileiro, Responsabilidade Civil. 12a ed.v. 4.São Paulo: Saraiva, 2017.

MACHADO, Paulo Affonso Leme, Direito Ambiental Brasileiro. 25 ed.São Paulo : Malheiros Editores.2017.

MACHADO, Paulo Affonso Leme. Princípios Gerais de Direito Ambiental Internacional e a Política Ambiental Brasileira. Revista de Informação Legislativa. Brasília, v. 118, p. 207-218, 1993.

NADER, Paulo. Curso de Direito Civil - Contratos. $7^{\text {a }}$ ed. Rio de Janeiro: Forense, $3^{\circ}$ vol.,2013.

NERY JR., Nelson e NERY, Rosa Maria .A.. Código Civil Comentado. $6^{\mathrm{a}}$. ed. São Paulo: Ed. Revista dos Tribunais.2008. 
NOGUEIRA NETO, Paulo. Uma Trajetória Ambientalista. São Paulo: Empresa das Artes,2010..

POUILLAUDE, Hugo-Bernard.Le lien de causalité dans le droit de la responsabilité administrative. Université Panthéon-Assas. Thèse de Doctorat. 13/12/2011.

POZZO, Barbara. Danno ambientale ed imputazione della responsabilità. Milano: Giuffrè Editote, 1996.

ROSEVALD, Nélson et all.. Código Civil Comentado. $4^{\mathrm{a}}$. Ed. Coordenador Ministro Cezar Peluso. Barueri: Manole.2011.

SARLET, Ingo Wolfang., MACHADO, Paulo Affonso Leme. eFENSTERSEIFER, Tiago. Constituição e Legislação Ambiental Comentadas. São Paulo: Saraiva, 2015.

STEIGLEDER, Annelise Monteiro. Responsabilidade Civil Ambiental: as dimensões do dano ambiental no direito brasileiro. Porto Alegre: Livraria do Advogado Editora, 2004.

VINEY, Genevièvee JOURDAIN, Patrice, com a colaboração de CARVAL, Suzanne. Traité deDroit Civil - Les Conditionsde la Responsabilité. 4e. Edition. Mayenne: LGDJ., 2013.

Recebido em: 08/01/2018 Artigo aceito em: 09/05/2018.

\section{Como citar este artigo (ABNT):}

MACHADO, Paulo Affonso Leme. STJ E NEXO CAUSAL NA RESPONSABILIDADE CIVIL. Veredas do Direito, Belo Horizonte, v. 15, n. 31, p. 351-371, jan./abr. 2018. Disponível em: $<$ http://www.domhelder. edu.br/revista/index.php/veredas/article/view/1224>. Acesso em: dia mês. ano. 